\title{
Teachers' Moral Competence in Pedagogical Encounters
}

\author{
Elina Kuusisto and Kirsi Tirri
}

\section{Introduction}

This chapter presents the Education for Democratic Intercultural Citizenship (EDIC) module called 'Teachers' moral competence in pedagogical encounters', which emphasises ethical sensitivity, a growth mindset in learning, and purpose in life. We explain the theories behind these three concepts and present empirical findings that show how these are needed to educate ethical professionals who promote intercultural and democratic education in schools.

In Finland, which is the context for this chapter, teachers are seen as autonomous and ethical professionals who have the pedagogical freedom to implement the values and educational goals of Finland's national core curriculum in their own way in their classrooms (Tirri, 2014). These values are (1) the uniqueness of each pupil and the right to a good education; (2) humanity, general knowledge and ability, equality and democracy; (3) cultural diversity as richness; and (4) necessity of having a sustainable way of living (Finnish National Board of Education, 2016, pp. 15-16). The core values acknowledge the importance of developing students as human beings and democratic citizens by emphasising equal opportunity for every student to learn, meeting students' individual needs, and engaging students in pro-social plans for their future. Basic education in Finland is based on respect for human rights, which in turn promote 'well-being, democracy and active agency in civil society' (Finnish National Board of Education, 2016, p. 16). School education is intended to support this kind of holistic growth, not only in the cognitive domain but also in the affective, moral, social, and behavioural domains.

School teachers instruct entire generations of children and young people in these common values. To do so, teachers must negotiate multiple views and student interests as well as the views and interests of parents, colleagues, school administrators and representatives of the society. Teachers thus need to be aware of the consequences of their actions; in other words, they need ethical sensitivity (Narvaez \& Endicott, 2008). In Finland the importance of moral competence for teachers has been made more pressing by the increasing

(C) KONINKLIJKE BRILL NV, LEIDEN, 2019 | DOI: 10.1163/9789004411944_005 
numbers of students and families from a wide array of socio-economic and cultural backgrounds. Ethical sensitivity has been found to be the most critical of the ethical abilities, as without it the ethical dimensions of a situation may not even be recognised. Finnish teachers typically feel that their educational programmes do not provide sufficient tools for dealing with the moral dilemmas and conflicts that challenge democracy and tolerance in schools (Tirri, 1999, 2017; Veugelers, de Groot, \& Stolk, 2017). Therefore, the first aim of the present module, 'Teachers' moral competence in pedagogical encounters', is to equip and educate future teachers with skills in ethical sensitivity so that they can develop democratic and intercultural citizenship proficiency and ethical attitudes in themselves as well as in their students.

In inclusive school systems such as Finland's, students at each grade level are taught together in the same classroom regardless of abilities until the age of 15 (Tirri \& Laine, 2017). This creates natural opportunities to learn mutual respect and dialogue, which are important skills in creating a sustainable and tolerant society. Inclusive education means that students with learning and behavioural challenges as well as gifted and talented students are taught in the same group. Teachers are expected to differentiate their instruction to provide individualised tuition and learning processes for all students. The Finnish educational system can be described as especially active in promoting the values of equality and individualism (Tirri, 2017, p. 84). Studies have shown that, in order to individualise and thus promote every student's development in the best possible way, understanding the role of mindsets in learning is essential (Rattan, Good, \& Dweck, 2012; Rissanen, Kuusisto, Hanhimäki, \& Tirri, 2018a, 2018b; Rissanen, Kuusisto, Tuominen, \& Tirri, 2019). Learning mindsets refer to implicit beliefs about whether or not human qualities such as intelligence, giftedness, and personality can be developed; a growth mindset (the incremental theory) holds that they can, while a fixed mindset (the entity theory) holds that these qualities are innate and fixed. A teacher's mindset has an impact on how, and even on whom, she or he instructs (Dweck, 2000; Rissanen et al., 2018a, 2019). Research indicates that teachers' implicit beliefs need to be identified and also challenged during teacher education (Rissanen et al., 2018a, 2018b, 2019). Teachers must learn to address their own belief systems and learn how to support growth mindset in their students, interfering when they notice fixed mindset-motivated behaviour with self-limiting patterns. It can be said that teachers' moral and professional responsibility in a democratic society is to have a growth mindset towards every student regardless of background or current competencies. Students with learning and behavioural problems as well as gifted students need to have tasks that provide sufficient challenges and opportunities to learn from their mistakes. Studies show that in intercultural 
societies students may face stereotyping, meaning that racial or gender stereotypes may unconsciously hinder the learning process (Aronson, Fried, \& Good, 2002). However, knowledge about mindsets and how beliefs systems work is one of the best educational tools for cultivating intercultural and democratic citizenship so that every student is supported in developing their agency and becoming active citizens who realise their potential to the full.

In today's societies young people can choose among countless opportunities. Some students navigate and thrive in such an environment, but a growing number of students have problems in choosing, making decisions, and keeping commitments. It has even been stated that the stress from which many young people are suffering is not rooted in having too much to do, but rather in having expectations that are too low or having no long-term goals for their lives (Damon, 2008). Our goal is to educate teachers who can reflect on the educational purposefulness of their calling from different points of view and who can help their students find purpose in their lives (Bundick \& Tirri, 2014). Democratic societies need citizens who are engaged in civic and political activities (Veugelers et al., 2017). Teachers can stimulate participation in civic activities as a means of promoting what will eventually be an effective democracy. This can achieved by building purpose, which includes beyond-the-self aspirations; in other words, supporting societal participatory skills and a responsible attitude towards the community and the future (Damon, 2008; Tirri, 2017, p. 85).

The EDIC module presented in this chapter approaches the topic from the perspective of three theories, which are believed to involve key factors in building teachers' moral competence, namely ethical sensitivity, growth mindset in learning, and purpose in life. These theories are presented in more detail in the next section.

\section{Theoretical Framework}

\subsection{Ethical Sensitivity}

We know from earlier empirical research that moral experts demonstrate holistic orientations and skill sets in four processes of ethical behaviour: ethical sensitivity, ethical judgement, ethical motivation, and ethical action (Bebeau, Rest, \& Narvaez, 1999). Although all these skills and attitudes are essential, the most important is ethical sensitivity because it is needed in order to recognise and to understand ethical problems and their symptoms. Our previous studies on ethical sensitivity in Finland and Iran (Gholami, Kuusisto, \& Tirri, 2015; Hanhimäki \& Tirri, 2009; Kuusisto, Tirri, \& Rissanen, 2012) have shown its importance in teaching and learning. Thus, we see ethical sensitivity as 
a possible key ingredient of teachers' moral competence for solving moral conflicts that threaten or challenge students' democratic and intercultural development.

Darcia Narvaez (Narvaez \& Endicott, 2008) has operationalized ethical sensitivity with seven dimensions: (1) reading and expressing emotions, (2) taking the perspectives of others, (3) caring by connecting with others, (4) working with interpersonal and group differences, (5) preventing social bias, (6) generating interpretations and options, and (7) identifying the consequences of actions and options. These dimensions illustrate that ethical sensitivity is about seeing the ethical aspect of a situation. Ethical sensitivity means being aware of one's own and other people's feelings and knowing how to express and regulate these feelings appropriately in a given situation. Taking the perspective of others indicates being able to take into account alternative viewpoints and look at a situation from another person's position.

A study conducted among Finnish and Iranian teachers found significant differences, especially with regards to this dimension (Gholami et al., 2015). For Finnish teachers, taking the perspective of others was a prerequisite for caring by connecting with others; in other words, Finnish teachers show caring by considering the viewpoint of the other person. However, this was not the case with the Iranian teachers; minding others' perceptions was not associated with caring. The result can be understood by taking into account the cultural differences between Finland and Iran: Finland is a country that supports individualistic values, whereas Iran advocates collectivist ones, and specifically values connected with the Iranian interpretation of Islam. Therefore, in Iran "in many social conflicts "individual agency" and people with secular values are ignored, while the "collective structure" and individuals with a sacred orientation are acknowledged' (Gholami et al., 2015, p. 902). The study by Gholami et al. also showed that caring by connecting with others is the central element in teachers' ethical sensitivity and a culturally invariant aspect of ethical sensitivity. Nevertheless, the manifestation of caring in terms of taking the perspective of others is dependent on culture.

Ethical sensitivity also means identifying, perceiving, and responding to diversity in a pro-social way, and understanding how one's own and others' positions, prejudices, and preconceptions are affecting an interaction. An ethically sensitive person shows compassion in generating interpretations, as one comprehends that people might make the same mistake over and over again because of automatic responses. And finally identifying the consequences of actions and options refers to the visualisation of and consideration given to multiple alternative strategies for proceeding in a given situation. 


\subsection{Growth Mindset for Learning}

Carol Dweck's (2000) theory of mindsets refers to the set of beliefs concerning whether intelligence, personality, and morality can be developed (a growth mindset) or cannot (a fixed mindset). In the everyday life of schools, teachers encounter various moral dilemmas, and their solutions to these reflect their values and beliefs. Also in the context of teaching and learning, mindset seems to play a crucial role in moral education (see Rissanen et al., 2018b) and could be one of the essential elements of teachers' moral competence.

Dweck's (2000) studies have consolidated the foundational role that mindsets play in learning. Mindsets influence one's perceptions of goals, efforts, mistakes, and morality. The goal of a person who has a fixed mindset is to look smart' and perform in a way that confirms a high level of intelligence. Efforts or mistakes are not valued. Instead, they are understood as signs of inability, which in turn leads to lying and to hiding failures and flaws. The attitudes of those who have a growth mindset are quite the opposite. The goal is to learn, to become smarter, which means that efforts and mistakes are understood as essential steps in learning. With a growth mindset a person does not have to hide mistakes or lie about them, as mistakes are seen as a natural part of the learning process. The idea is that everyone can learn; however, we should realise that people have different possibilities and conditions for learning.

Mindsets are developed in encounters with parents, teachers, and the surrounding society and culture. The most important factor in forming mindsets has been found to be feedback (Mueller \& Dweck, 1998). Praise and criticism should be directed towards processes, such as learning strategies and effort. In addition, the use of the phrase 'not yet' in expressing criticism allows room for improvement and motivates a person to carry on (Ronkainen, 2018). The focus on process can be regarded as the core of growth mindset pedagogy (Rissanen et al., 2019). Person-orientated praise and criticism should be avoided, as this kind of feedback consolidates a fixed mindset, which in turn promotes helpless responses and makes students vulnerable in coping with challenges and mistakes (Kamins \& Dweck, 1998; Mueller \& Dweck, 1998). Dweck's studies have shown that even though mindsets are relatively stable, they can be changed over a long period of time and even primed for a shorter period. Therefore, it is important that teachers learn about Dweck's theory so that they recognise how mindsets are actualised in everyday life in their classrooms. Teachers also need to learn how to support the development of a growth mindset in their students.

Beside process focus, growth mindset interventions illustrate that another key factor in supporting growth mindset has been teaching students about neurogenesis and neuroplasticity (Blackwell, Trzesniewski, \& Dweck, 2007; 
Schmidt, Shumow, \& Cam-Kakar, 2015). Images of 'brains as muscles' have been found to help students visualise what is happening in their brains when they practise and put effort into learning. Understanding how brains function enables students to understand why learning can be challenging, and in fact must be challenging, and why repetition is crucial. Studies also show that in order to keep up the results of interventions, teachers need to be engaged in constantly reminding students about growth mindset practices (Schmidt et al., 2015).

\subsection{Purpose in Life}

The notion of 'purpose' is the most profound phenomenon of human experience, as it provides reasons not only for acting ethically but also for living. Research has found powerful links between the pursuit of positive purpose and life satisfaction (Damon, 2008). In the view of Damon, purpose promotes pro-social behaviour, moral commitment, achievement, and high self-esteem. Purpose has a social orientation; therefore, individualism or a strong orientation to one's own life is not considered to be a purpose. Instead, purposelessness is associated with such matters as depression, addictions, deconstructive behaviour, and lack of productivity. In 2002 the British government was the first to officially identify a growing phenomenon: young people who were neither in school nor in training nor employed (NEET) (Damon, 2008), suggesting an increasing number of youngsters who lack purpose in their lives and struggle to find a meaningful life. Given these findings, we argue that the ability of teachers to foster students' sense of purpose could also be one of the key elements of teachers' moral competence.

The interest in studying purpose and the meaning of life in fields of psychology and educational sciences peaked for the first time in the 196os. Still, it should be noted that these topics were being discussed long before that time in philosophy and theology. The interest in the 196os was generated by Viktor Frankl's Man's Search for Meaning, first published in 1958. In this book Frankl describes his experiences as a Holocaust survivor and how, during his imprisonment, he observed that those who had a purpose and those who were able to find meaning in suffering were the ones who were able to cope with the horrible conditions. He found that high levels of belief systems can enable human beings to endure life's hardships and that, regardless of circumstances and environment, we have the mental freedom to choose our attitude.

Based on Frankl's work, Damon, Menon, and Bronk (2003) have constructed a theory that defines purpose as a stable, long-term goal to contribute to the world beyond the self and is also meaningful to the self (Damon, Menon, \& Bronk, 2003; Damon, 2008). This multi-dimensional conceptualisation indicates that real purpose is a concrete goal. Purpose is something that can be 
identified and aspired to. Secondly, purpose is not only a dream, but also something that one is engaged in realising and actualising by making plans and choosing activities with which to reach the goal. Thirdly, purpose is meaningful to oneself. Purpose is something that one is impassioned about and finds to be profoundly important. Fourthly, purpose not only benefits oneself, but also others. This 'other' focus provides a pro-social aspect to the definition formulated by Damon et al. (2003).

Within this framework it is said that everyone can find a purpose, and moreover, purpose can be taught and its development supported (Tirri \& Kuusisto, 2016). Purpose can be taught in schools with methods that are both explicit and implicit. Explicit methods help students to process their desires, values, and aspirations intentionally and learn and reflect on inspiring life histories, such as Viktor Frankl's. By discussing purposes, teachers model adults who are able to deliberate on the future orientation of students and who hopefully have found their own purposes in life. Implicit methods mean that students' purpose development is supported through all kinds of teaching, regardless of the subject matter or content, by enlightening students and helping them to understand the personal and societal relevance of the studied content. For example, in science classes students may be asked to write a brief essay describing how the materials studied that week could be applied in their lives (Hulleman \& Hrackiewicz, 2009).

\subsection{Aims of the Module and Curriculum Guidelines}

In this module our objective will be to equip future teachers with moral competence so that they know how to support their pupils' holistic growth to become active citizens engaged in intercultural communication. The module will draw on Finnish research-based teacher education, the goal of which is to educate autonomous professionals who are committed to promoting values of equality, individualism, tolerance, and democracy (Tirri, 2017). In Finland teaching has a strong moral dimension, and teachers are considered to be moral professionals (Tirri, 2014). Thus, in this module student teachers will learn to cultivate their moral competence by participating in various ideological, pedagogical, and intercultural negotiations. In the course of the module, student teachers will collaborate in international teams while they jointly produce a mini-study and prepare a teaching session which they will hold. By conducting, learning, and following scientific conventions in doing small-scale research projects, students develop their critical thinking skills and learn to apply and evaluate theoretical and practical perspectives in moral competence.

In this module student teachers will learn about moral professionalism in teaching and holistic school pedagogy (Tirri, 2011). They will learn to identify 
and solve moral dilemmas and conflicts in schools and cultivate their ethical sensitivity by communicating and comparing their views with student teachers from different European and non-European countries (Hanhimäki \& Tirri, 20og; Hedayati, Kuusisto, Gholami, \& Tirri, 2017a; Tirri, 1999). They will learn how implicit theories about intelligence affect teaching and learning, and they will practise feedback styles, which have been found to improve learning outcomes significantly and reduce stereotype threat (Aronson et al., 2002; Dweck, 200o; Rattan et al., 2012; Rissanen et al., 2018a, 2018b, 2019; Schmidt et al., 2015). They will also study how to support their pupils' purpose in life (Bundick \& Tirri, 2014), given that today, a general lack of purpose is associated with the stress that people are experiencing and with apathy in the young (Damon, 2008).

The module builds on the principle of 'We teach what we research, and we research what we teach', which captures the ethos of research-based Finnish teacher education (Tirri, 2014). The module is designed so that students learn the theories that have been suggested as the core elements of teachers' moral competence by reflecting on and analysing their own perceptions. They learn to identify theoretical concepts in real-life contexts, and apply theories in collaborating and teaching in international and intercultural teams. For example, in 2017 the module had 25 international students representing 14 different countries. In the course of the module, the students constantly put into practice the theories they were studying. They also practised scientific thinking and knowledge construction. The module offers tools for analytical thinking and experience in using research methods. After completing the module, students will have:

- Knowledge of teachers' moral competence and students' holistic growth in a school context

- Skills to apply their learning to different practices in the teaching profession

- Skills in critical thinking and drawing conclusions

- Knowledge of the interactional relationship between theory and practice

- Understanding of peer-group support in teachers' work

- And, hopefully, an attitude that shows how important these skills are in themselves and a desire to use these skills to contribute to a democratic intercultural society.

\subsection{Schedule, Instructions, and Evaluation}

The module 'Teachers' Moral Competence in Pedagogical Encounters' is designed to be taught during one month's time: two weeks are devoted to 
intensive study and two weeks are used to finalise the course tasks (Table 5.1). The module consists of a commentary, a course diary, lectures, and group work on one of the module topics (Table 5.2). Each student will write a commentary and an individual course diary. The commentary is to be written during the first week of the module. Each student writes a commentary on an article related to one of the group's topics. The commentary is presented and discussed in the four groups, based on the topic in self-directed meetings. The aim is that all group members become familiar with the articles related to the topic of their group work.

In the course diaries, students reflect on the contents of the module in light of the research literature and from each of their own perspectives, while also explicating their personal learning process. In the diary students are expected to apply theoretical concepts, compare articles, and express their opinions, i.e. evaluate and use what they have heard and read during the module.

In the group work, students carry out a mini-study on one of the theoretical perspectives of teachers' moral competence. The data for the mini-studies are gathered during lectures. During guided group work, the students analyse and write their mini-study and also prepare power point slides, which are presented on the last day of the module in a mini-conference.

Based on the individual learning diaries and the groups' mini-studies, students are evaluated on a scale of 0 to 5 ( $O=$ fail, $1=$ lowest grade, $5=$ highest grade). The evaluation criteria are given in Table 5.3. Students earn 5 ECTs in this module. In addition, they have the opportunity to write an optional essay $(2.5$ ЕСT $)$ based on the following instructions:

Choose one of the course topics which was not the topic of your ministudy (ethical sensitivity, moral dilemma, mindset, purpose). Read a minimum of three articles and make reference to these articles as you answer the following question: Why is [this theory/theoretical framework] important from the perspective of teachers' moral competence in pedagogical encounters? Write an essay $5^{-10}$ pages in length. Use APA style in references and in the list of references.

\subsection{Examples of Students' Mini-Studies}

In this section we present examples of mini-studies from a module that was arranged in November 2017 at the University of Helsinki, Finland. Participants included 25 students (Female $n=20$, Male $n=5$, Age $M=22.25, S D=2.801$ ) from 14 different countries. All students were studying educational sciences. The mini-studies addressed four topics: ethical sensitivity, moral dilemmas, mindsets about learning, and purpose in life. Each group was given a theory along 

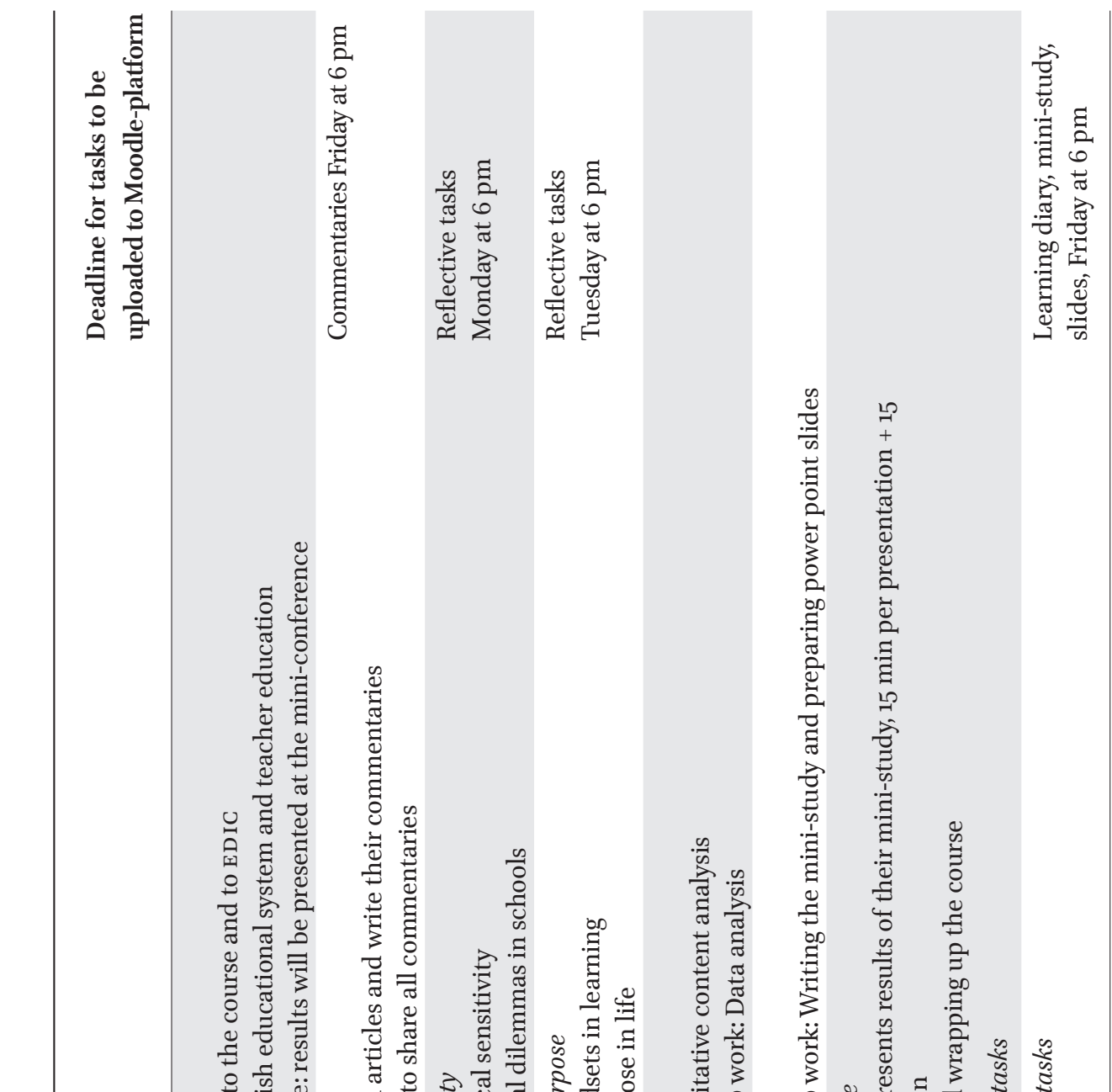

$$
\text { (n) }
$$

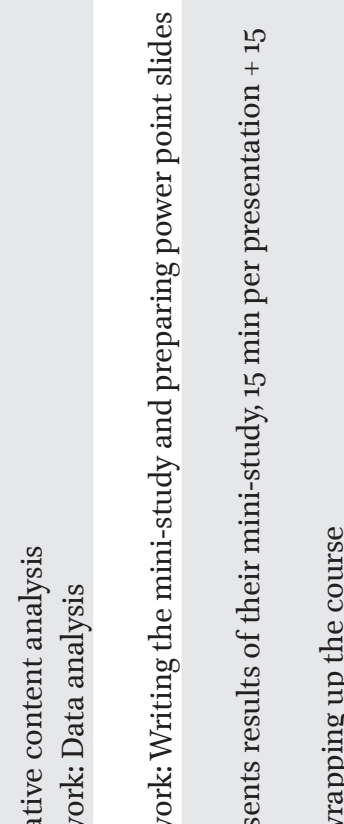

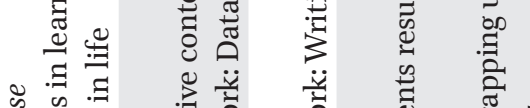

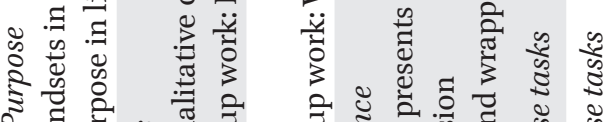

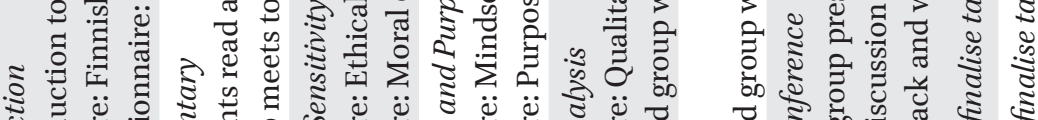

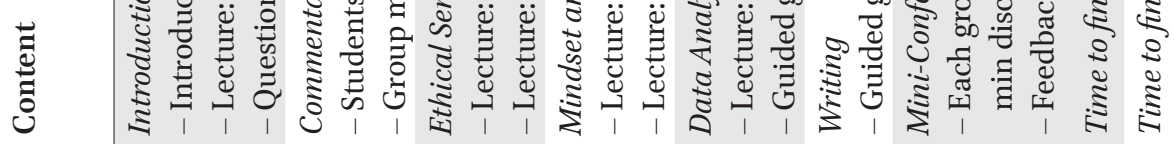

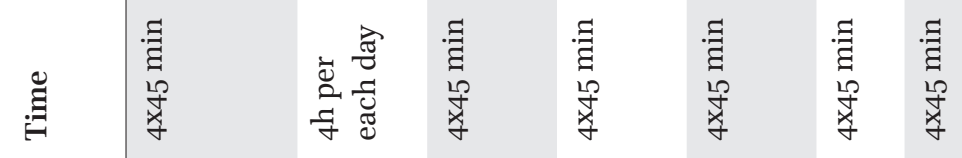
䓛蛋 胥

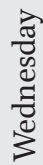
苞 胥 


\section{Commentary (individual and group tasks)}

The commentary task is given on the first Monday. Students have one week to complete the task. Each student writes a commentary on an article related to one of the group's topics. Group topics: Moral dilemma, Ethical sensitivity, Mindset, Purpose. At the end of the first week each student presents the commentary to the group members.

Commentary and question: a question is open, an argument is closed. An argument demands reacting, which enhances interaction. It reveals gaps in your knowledge and skills. It leads to searching, justification and sharing information. It precedes finding the answer. It transfers the viewpoint from the present situation to the examination of new possibilities.

When you read, try to determine: What is the author's aim? What is his/her main idea? What does the author mean by the 'big picture' (of the article) or by a specific detail? What does the author argue for/ask about/criticise/summarise? How does the author justify his/her arguments?

After careful and thorough reading, write down at least two comments or questions about the article. Your aim is to have one of the comments or questions deal with the article's main idea and the other deal with a more specific point or detail in the article. Commentaries are thorough arguments; they consist of a short background to the topic followed by a question or comment. The length of the commentary is between 15 lines to half a page. Each participant shares their commentary in the group meeting and each article is discussed so that every member of the group has a good understanding of the message of every article.

\section{Learning diary (individual task)}

Write a learning diary at the end of each of the 6 days (max one page):

a. What did you learn today about teachers' moral competence in educational encounters?

b. What would you like to know/ask more about?

c. How is the knowledge you learned today related to your professional and personal life?

\section{Mini-study (group task)}

Title page (Title, authors' names)

1 Introduction (Why this study is important, theory, context, research question)

2 Data and methods

2.1 Participants

2.2 Data gathering

2.3 Data analysis (Deductive or inductive content analysis)

3 Results

4 Discussion (What were the research questions? What were the answers? What do the results mean in light of the theory? What were the limitations of the study, future studies?) 
TABLE 5.2 Instructions for the course tasks (cont.)

\section{Upload to Moodle as one document in References}

Doc, docx or pdf-format

Font size 12, double-spaced

Include your name, Student ID, Date

APA style: references and list of

references http://www.apastyle.org/

Length: $5^{-10}$ pages, font size 12 , double-

spaced lines

APA style: references and list of references

http://www.apastyle.org/

Writing style 'This study investigates ...',

'The data were categorised by utilizing

deductive content analysis ..."

Data gathering for the mini-studies (individual tasks)

Data are gathered during lectures on Mondays and Tuesdays

Reflective tasks related to each topic will constitute the research data.

Students upload the texts to Moodle at the end of the day. Name will not be included to the data, but it is important so that each group does not analyse its own answers. In addition, at the end of the text write your gender, age, and nationality.
Power point presentation (group task)

Based on the group's mini-study $5^{-10}$ slides including text, figures, tables, pictures

10-15 $\mathrm{min} /$ presentation

During presentations, other groups make notes in their course diaries and create $1-3$ questions related to each presentation.

TABLE 5.3 Evaluation criteria for the learning diary and the mini-study

\section{Grade Course diary and mini-study}

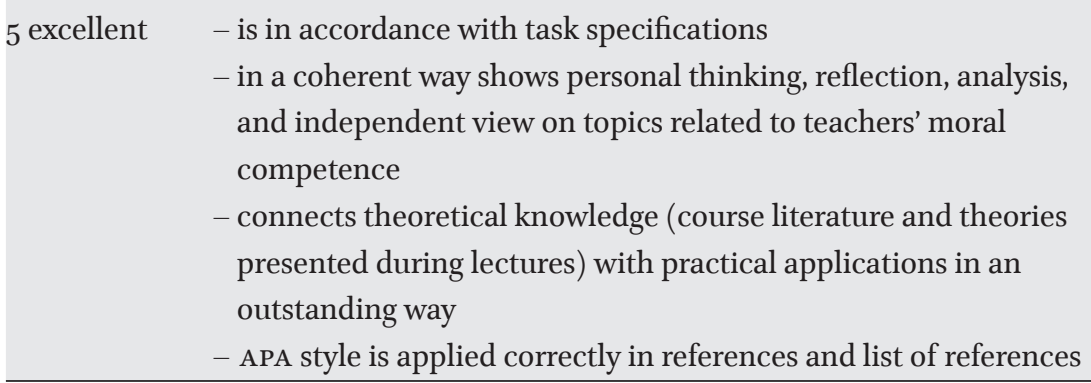

(cont.) 
TABLE 5.2 Evaluation criteria for the learning diary and the mini-study (cont.)

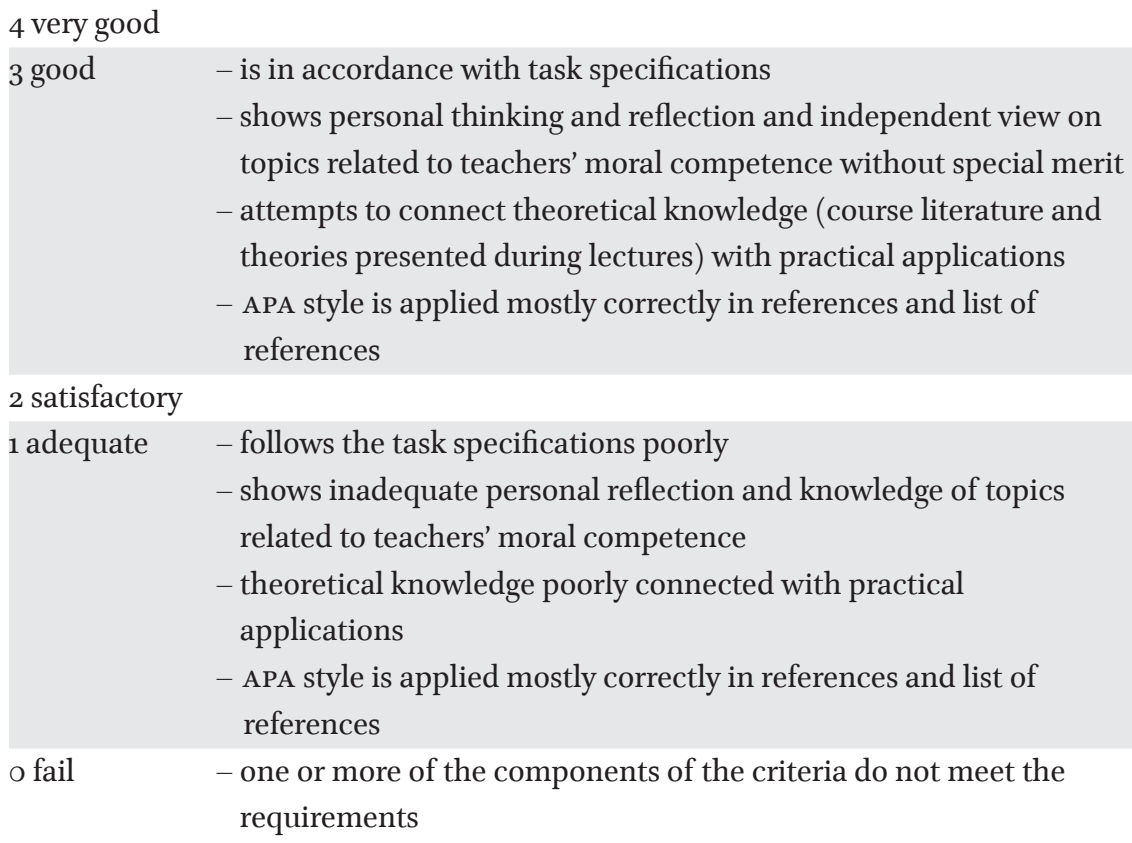

with articles for reference, a basic research question to be further modified, and data collected during the lectures. The data included answers from every student who participated in the course. However, the small groups did not analyse their own data, but rather analysed the students' answers from other groups. The aim was to teach and apply the rules of scientific research. The students were also taught to conduct qualitative content analysis deductively and inductively in line with Elo and Kyngäs's (2008) article. Table 5.4 shows the topics, research questions, theoretical articles, data-gathering instruments, analytical methods and questions for discussion used by the groups in November 2017. The next section presents the results of the students' mini-studies, tables introducing categories, frequencies of the sentences coded into each category, and examples from the data.

\subsubsection{Results of the Ethical Sensitivity Group}

The ethical sensitivity group found that 'Caring by connecting to others' appeared in most of the stories $(n=18)$, while the other dimensions occurred fewer than 5 times (Table 5.5). Ethical sensitivity was shown with 'oral support', which was mentioned 11 times, with 'Practical support' found 16 times, 


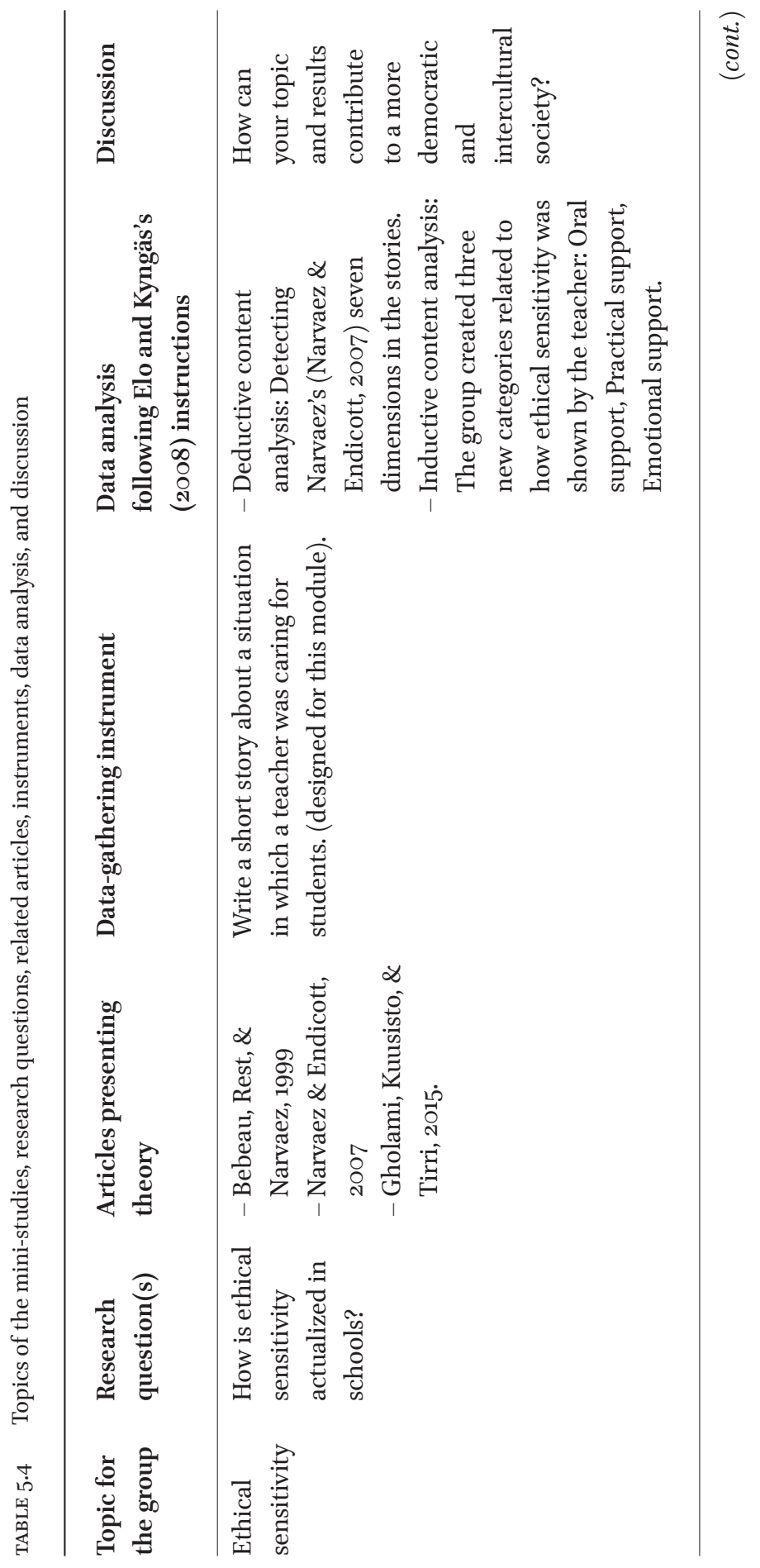




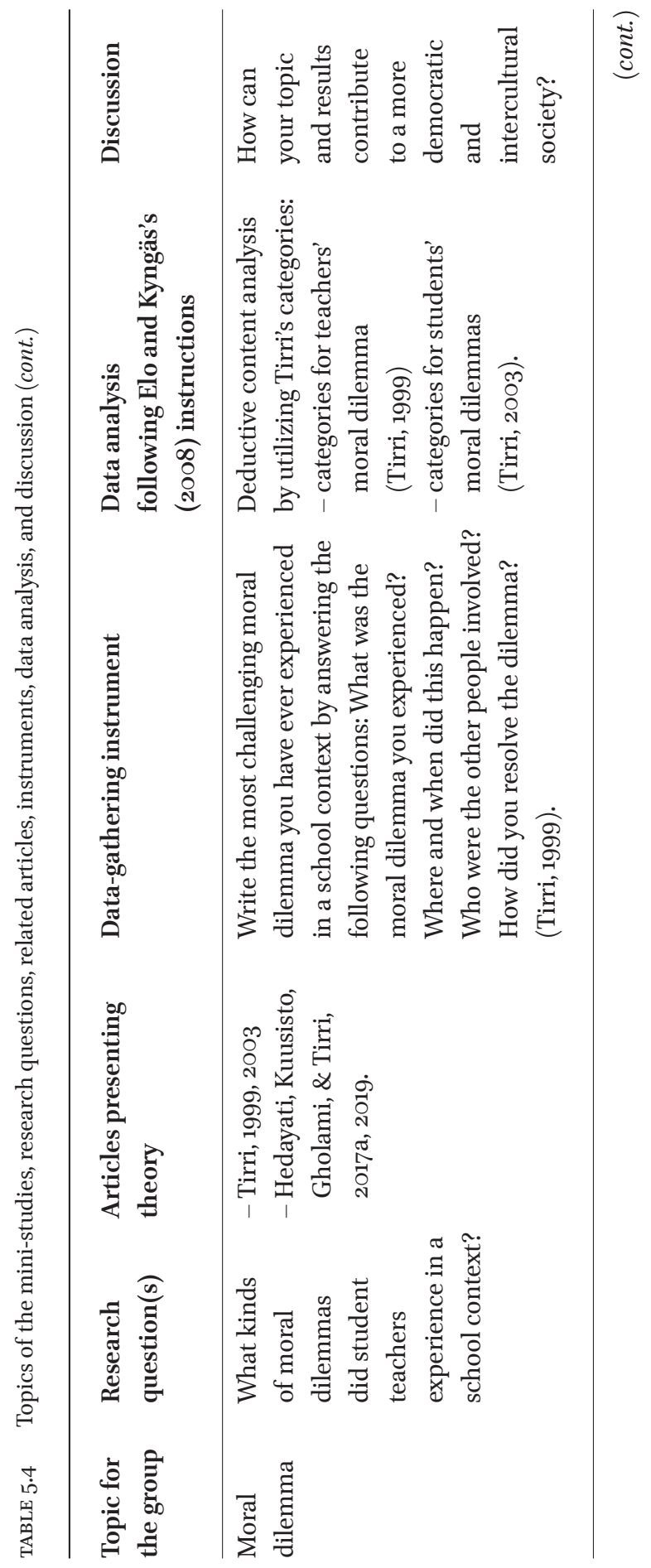




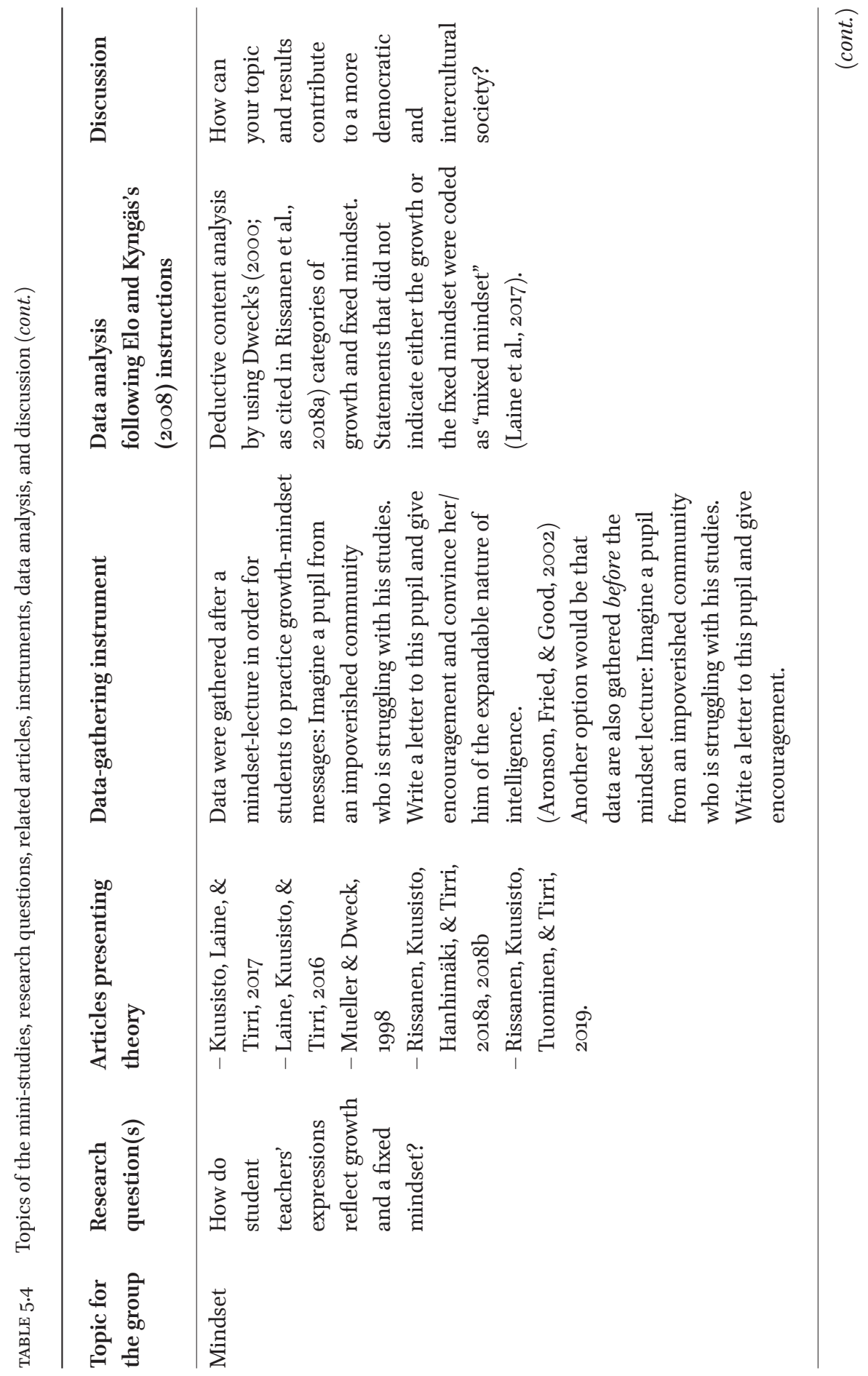




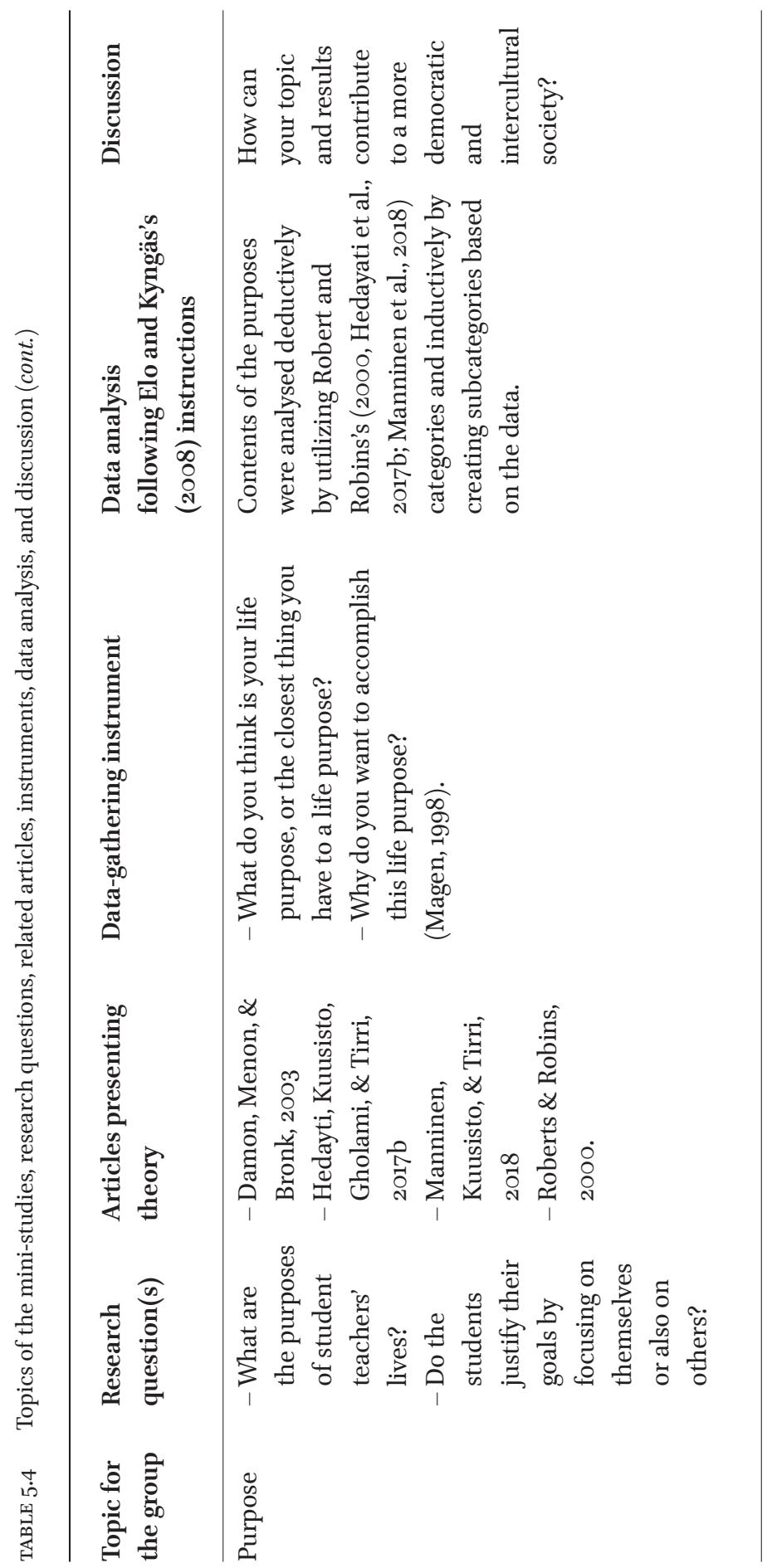


TABLE 5.5 Ethical sensitivity group: Dimensions of ethical sensitivity

\begin{tabular}{|c|c|c|}
\hline Dimensions of ethical sensitivity & F & Examples from the data \\
\hline Reading and expressing emotions & 3 & - The teacher saw that she was crying. \\
\hline Taking the perspective of others & 2 & $\begin{array}{l}\text { - My teacher arranged rides to visit our } \\
\text { sick colleague so he is not so bored. }\end{array}$ \\
\hline Caring by connecting with others & 18 & $\begin{array}{l}\text { - She took time to talk to this friend who } \\
\text { was very upset. }\end{array}$ \\
\hline $\begin{array}{l}\text { Working with interpersonal and } \\
\text { group differences }\end{array}$ & 1 & $\begin{array}{l}\text { - The teacher invited us to her home to } \\
\text { prepare the presentation. }\end{array}$ \\
\hline $\begin{array}{l}\text { Generating interpretations and } \\
\text { options }\end{array}$ & 5 & $\begin{array}{l}\text { - That's when the teacher introduced me } \\
\text { to a programme in our school for only } \\
\text { the best students. }\end{array}$ \\
\hline $\begin{array}{l}\text { Identifying consequences of } \\
\text { actions and options }\end{array}$ & 1 & $\begin{array}{l}\text { - The teacher also negotiated with the } \\
\text { other school teachers so that when } \\
\text { the student returns to school the } \\
\text { teachers don't put too much pressure } \\
\text { on her [...]. }\end{array}$ \\
\hline
\end{tabular}

Preventing social bias

0

whereas 'Emotional support' appeared only 3 times (Table 5.6). The group also combined their analyses on ethical sensitivity and teachers' support and found that caring was shown both orally and practically (Figure 5.1). Emotional support appeared only when a student was reading and/or expressing emotions.

\subsubsection{Results of the Moral Dilemma Group}

The moral dilemmas identified by the students were written from the perspective of teachers and students (Table 5.7). Teachers' dilemmas $(n=8)$ were related to the teachers' work, the students' work, and general school rules. Students' dilemmas $(n=13)$ were related to teacher behaviour, peer relations, general school rules, and harassment.

\subsubsection{Results of the Mindset Group}

In all, the group found 61 growth-mindset statements, 7 fixed-mindset statements, and 6 mixed-mindset statements in letters to an impoverished pupil. The results indicate that most of the students showed that they had understood the idea of a growth mindset and were able to use it in their letters. The results might have been different had the letters been written before the lesson 
TABLE 5.6 Ethical sensitivity group: Teachers' ways of showing support

\begin{tabular}{|c|c|c|}
\hline Ways of showing support & F & Examples from the data \\
\hline Oral support & 11 & $\begin{array}{l}\text { - Every week the teacher would ask if I was ok } \\
\text { and how my mum was doing. }\end{array}$ \\
\hline Practical support & 16 & $\begin{array}{l}\text { - The teacher heard [that the student's } \\
\text { father could not participate] and decided } \\
\text { to accompany the student to the [school] } \\
\text { ceremony as her "father" or representing one } \\
\text { of her family members. }\end{array}$ \\
\hline Emotional support & 3 & $\begin{array}{l}\text { - The teacher always noticed when we had a } \\
\text { problem between us or at home. }\end{array}$ \\
\hline
\end{tabular}

Teachers' supports in ethical sensitivity

Oral support $\square$ Practical support Emotional support

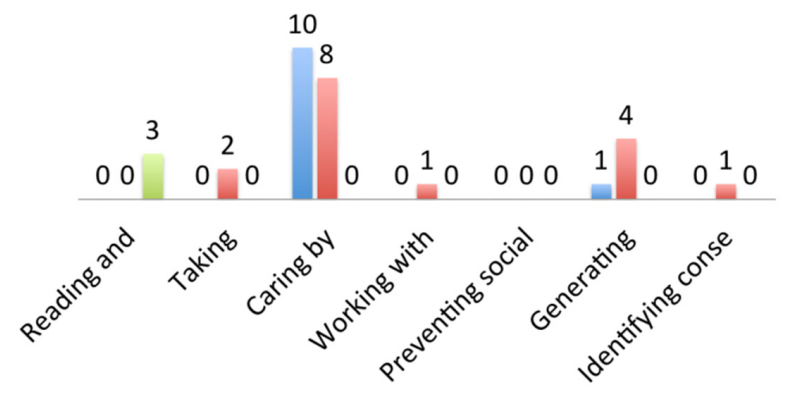

FIGURE 5.1 Teachers' support in ethical sensitivity

on mindsets. Categories, sub-categories, and examples from the data are presented in Table 5.8 .

\subsubsection{Results of the Purpose Group}

The purpose group found a total of 36 different life goals which students desired to achieve (Table 5.9). The first main category was called 'Meaningful for the self', which included two subcategories: 'Family and relationships', referred to as family and stable relationships and self-acceptance, and 'Economic and hedonistic', which meant that students pursued a successful and secure job, a good place to live and happiness. 
TABLE 5.7 Moral dilemma group: Teachers' and students' perceptions of moral dilemmas in schools

$\begin{array}{lllll}\text { Main Subcategories } & \text { F } & \text { F } & \text { Examples from the data } \\ \text { categories } & & & & \\ \end{array}$

\begin{tabular}{|c|c|c|c|}
\hline \multirow{4}{*}{$\begin{array}{l}\text { Teachers' } \\
\text { moral } \\
\text { dilemmas }\end{array}$} & & & \\
\hline & Teachers' work & 5 & $\begin{array}{l}\text { - I could be creating a conflict that could } \\
\text { ruin the positive teaching environment } \\
{[\ldots] \text { and the consequences }[\ldots] \text { were not }} \\
\text { necessary as he didn't usually behave } \\
\text { like that. }\end{array}$ \\
\hline & $\begin{array}{l}\text { Morality of the } \\
\text { students }\end{array}$ & 2 & $\begin{array}{l}\text { - Last semester when I did my internship } \\
\text { in a secondary school }[. . .] \text { there was a } \\
\text { little girl who usually got really good } \\
\text { marks }[. . .] \text { who came to me and told me } \\
\text { that she could not study the day before } \\
\text { [...] after a while I saw her cheating } \\
\text { looking at her neighbour's paper. I } \\
\text { decided not to say anything. }\end{array}$ \\
\hline & $\begin{array}{l}\text { General school } \\
\text { rules }\end{array}$ & 1 & $\begin{array}{l}\text { - Sexual relations were forbidden in the } \\
\text { summer programme. We found signals } \\
\text { of sexual relations in one of the rooms, } \\
\text { but we did not have evidence of who } \\
\text { was involved. We reported the issue to } \\
\text { the head of the company [sponsoring } \\
\text { the summer school] and informed the } \\
\text { families. }\end{array}$ \\
\hline
\end{tabular}

Students'

moral

dilemmas

$\begin{array}{lll}\begin{array}{l}\text { Teacher } \\ \text { behaviour }\end{array} & 2 & \begin{array}{l}\text { Consequently, we were punished } \\ \text { severely but we could win the games. }\end{array} \\ \text { Peer relations } & 6 & \begin{array}{l}\text { The dilemma was whether to turn my } \\ \text { friend in to be the only one punished for } \\ \text { that action. }\end{array} \\ & \end{array}$

(cont.) 
TABLE 5.7 Moral dilemma group: Teachers' and students' perceptions of moral dilemmas in schools (cont.)

\begin{tabular}{lllll}
\hline $\begin{array}{l}\text { Main } \\
\text { categories }\end{array}$ & Subcategories & F & F & Examples from the data \\
\end{tabular}

\begin{tabular}{lcl}
\hline General school $3 \quad$ & The father of one of my friends had \\
rules & been sick the day before the exam \\
& and she did not have time to study. \\
& I know she is a good student, and it \\
& was not about being lazy. I did not \\
& know whether to tell him the answers \\
& or not. \\
& One of my friends was being bullied. \\
& I was in 8th grade and I did not know \\
& if I should tell the teacher or not. '[...] \\
& I was picked on a little bit [by the \\
& bullies], about my background because \\
& I was half Chinese and half Japanese \\
& {$[\ldots]$ I was told if I wanted to join their } \\
& group, I had to stop saying that. \\
& And I did'.
\end{tabular}

The second main category was 'Beyond the self'. Students aspired to 'Act in public life', meaning that the students wanted to contribute to the well-being of society by teaching and become (good) teachers. They also desired to be 'social' by helping others and connecting with people from different cultures. The third main category was called 'No sense of purpose', indicating that students did not acknowledge a purpose or did not want to express their deep-seated aspirations.

This chapter presented the EDIC (Education for Democratic Intercultural Citizenship) module called 'Teachers' moral competence in pedagogical encounters', which was intended to provide student teachers with theoretical and practical tools with which to foster democratic and intercultural citizenship in their future pupils. This chapter presented the idea that ethical sensitivity, a growth mindset about learning, and purpose in life are possible core elements 
TABLE 5.8 Mindset group: Categories, subcategories, and examples from the data

\begin{tabular}{|c|c|c|c|}
\hline Main category & Sub-category & F & Examples from the data \\
\hline \multirow{4}{*}{$\begin{array}{l}\text { Growth } \\
\text { mindset } \\
\mathrm{f}=61\end{array}$} & $\begin{array}{l}\text { Perseverance and } \\
\text { learning as a process }\end{array}$ & 14 & - Don't be afraid to make mistakes. \\
\hline & Learning as a goal & 4 & $\begin{array}{l}\text { - The process of trying to learn is far } \\
\text { more important than the product of } \\
\text { your learning. }\end{array}$ \\
\hline & $\begin{array}{l}\text { Context-based } \\
\text { interpretation of } \\
\text { behaviour }\end{array}$ & 2 & $\begin{array}{l}\text { - You are struggling with learning now, } \\
\text { but it is important to remember that } \\
\text { everyone has times when they feel like } \\
\text { this. }\end{array}$ \\
\hline & $\begin{array}{l}\text { Encouragement } \\
\text { and safe learning } \\
\text { environment }\end{array}$ & 24 & - Ask me for help. \\
\hline \multirow[t]{2}{*}{$\begin{array}{l}\text { Fixed mindset } \\
\mathrm{f}=7\end{array}$} & Performance goals & 3 & $\begin{array}{l}\text { - Your parents and I know that it's so } \\
\text { important that you achieve good } \\
\text { results on exams. }\end{array}$ \\
\hline & Fixed personal traits & 4 & - You are a very smart boy. \\
\hline $\begin{array}{l}\text { Mixed mindset } \\
\mathrm{f}=6\end{array}$ & & & $\begin{array}{l}\text { - Failure is something that doesn't } \\
\text { exist. } \\
\text { - Nobody knows everything. }\end{array}$ \\
\hline
\end{tabular}

of teachers' moral competence, aspects that teachers need in order to carry out the ethical responsibilities of their profession.

The module's pedagogical idea was to teach the above core elements by combining lectures, personal reflections, and group work. The goal was for students to learn to apply theories in intercultural real-world contexts and learn to identify, acknowledge, and apply the theoretical issues on both personal and professional levels. The idea was also to teach students collaborative skills and make sure they understood components of the research process and how scientific knowledge is constructed.

Student teachers who participated in the module at the University of Helsinki in the autumn of 2017 felt that the topics and the course were educative. It provided important tools and practices for their future work as teachers. Theories, practical applications, and self-reflection were seen as important for the learning process. The course was an intensive one. The students' main 
TABLE 5.9 Purpose group: Categories, subcategories, and examples from the data

\section{Categories}

f Examples from the data

\begin{tabular}{|c|c|c|c|c|}
\hline \multirow[t]{4}{*}{$\begin{array}{l}\text { Meaningful for } \\
\text { the self } \\
f=17\end{array}$} & $\begin{array}{l}\text { Family and } \\
\text { relationship }\end{array}$ & $\begin{array}{l}\text { Family } \\
\text { Self-acceptance }\end{array}$ & $\begin{array}{l}5 \\
1\end{array}$ & $\begin{array}{l}\text { - I want to have a family. } \\
\text { - I'm trying to achieve self } \\
\text { acceptance. }\end{array}$ \\
\hline & $\begin{array}{l}\text { Economic } \\
\text { and }\end{array}$ & $\begin{array}{l}\text { Successful and } \\
\text { secure job }\end{array}$ & 2 & - I want to have a safe job. \\
\hline & hedonistic & Good place to live & 1 & $\begin{array}{l}\text { - I want to have a good place } \\
\text { to live. }\end{array}$ \\
\hline & & Happiness & 8 & - I want to be happy. \\
\hline \multirow[t]{4}{*}{$\begin{array}{l}\text { Beyond the } \\
\text { self } \\
f=17\end{array}$} & $\begin{array}{l}\text { Active in } \\
\text { public life }\end{array}$ & $\begin{array}{l}\text { Contribute to } \\
\text { the well-being of } \\
\text { society by teaching }\end{array}$ & 7 & $\begin{array}{l}\text { - [I want to] be remembered as } \\
\text { a positive contributor within } \\
\text { society". }\end{array}$ \\
\hline & & $\begin{array}{l}\text { Becoming a (good) } \\
\text { teacher }\end{array}$ & 3 & $\begin{array}{l}\text { - I want to be a good teacher } \\
\text { and share this described } \\
\text { ability with them. }\end{array}$ \\
\hline & Social & Help others & 5 & $\begin{array}{l}\text { - [I want to]reach a point } \\
\text { where I'm also able to help } \\
\text { others with their own growth } \\
\text { and well-being. }\end{array}$ \\
\hline & & $\begin{array}{l}\text { Connecting with } \\
\text { people from } \\
\text { different cultures }\end{array}$ & 2 & $\begin{array}{l}\text { - By travelling, you learn a } \\
\text { lot about prejudice and } \\
\text { stereotypes as well as } \\
\text { different world views. }\end{array}$ \\
\hline No purpose & & & & - I would not say that right now \\
\hline$f=2$ & & & & I have a life purpose. \\
\hline
\end{tabular}

criticism was that the schedule was too tight. For this reason, the module was modified to last for one month, as presented in this chapter. The module now includes more time for students to process the research literature and finalise their learning diary and group tasks. The course could be developed further by including school visits or excursions to non-governmental organizations that promote the human rights of students in school. During the first week of the module, participating students could also interview teachers and thereby learn more about the real-world aspects of intercultural realities in schools today as well as how teachers' moral competence and society's moral and democratic values are constructed and challenged in classrooms. 
Teaching ethical professionals how to promote democratic and intercultural education in schools is the main task of Finnish teacher education (Tirri, 2014). Teachers are expected to become holistic educators who help students become good democratic citizens and active agents who can encounter diversities in their society in a constructive manner. For this task teachers need moral competence, or in other words, ethical sensitivity, a growth mindset about learning, and purpose in life.

\section{References}

Aronson, J., Fried, C. B., \& Good, C. (2002). Reducing the effects of stereotype threat on African American College Students by shaping theories of intelligence. Journal of Experimental Social Psychology, 38, 113-25.

Bebeau, M., Rest, J., \& Narvaez, D. (1999). Beyond the promise: A perspective on research in moral education. Educational Researcher, 28(4), 18-26.

Blackwell, L. S., Trzesniewski, K. H., \& Dweck, C. S. (2007). Implicit theories of intelligence predict achievement across an adolescent transition: A longitudinal study and an intervention. Child Development, 78(1), 246-263.

Bundick, M., \& Tirri, K. (2014). Teacher support and competencies for fostering youth purpose and psychological well-being: Perspectives from two countries. Applied Developmental Science, 18, 148-162.

Damon, W. (2008). The path to purpose. New York, NY: Free Press.

Damon, W., Menon, J., \& Bronk, K. C. (2003). The development of purpose during adolescence. Applied Developmental Science, 7(3), 119-128.

Dweck, C. S. (200o). Self-theories. Their role in motivation, personality, and development. New York, NY \& London: Psychology Press, Taylor \& Francis Group.

Dweck, C. S. (2006). Mindset: The new psychology of success. New York, NY: Ballantine Books.

Elo, S., \& Kyngäs, H. (2008). The qualitative content analysis process. Journal of Advanced Nursing, 62, 107-115.

Finnish National Board of Education. (2014). National core curriculum for basic education. Helsinki: Finnish National Board of Education.

Frankl, V. E. (1988). Man's search for meaning. New York, NY: Pocket Books.

Gholami, K., Kuusisto, E., \& Tirri, K. (2015). Is ethical sensitivity in teaching culturally bound? Comparing Finnish and Iranian teachers' ethical sensitivity. Compare: A Journal of Comparative and International Education, 45, 886-907.

Gunderson, E. A., Gripshover, S. J., Romero, C., Dweck, C. S., Goldin-Meadow, S., \& Levine, S. C. (2013). Parent praise to 1-3-year-olds predicts children's motivational frameworks 5 years later. Child Development, 84, 1526-1541. 
Hanhimäki, E., \& Tirri, K. (2009). Education for ethically sensitive teaching in critical incidents at school. Journal of Education for Teaching, 35, 107-121.

Hedayati, N., Kuusisto, E., Gholami, K., \& Tirri, K. (2017a). Gender-specific religious moral dilemmas in Iranian schools. In R. Elmesky, C. Yeakey, \& O. Marcucci (Eds.), The power of resistance: Culture, ideology and social reproduction in global contexts (pp. 365-381). London: Emerald Group Publishing Limited.

Hedayati, N., Kuusisto, E., Gholami, K., \& Tirri, K. (2017b). Life purposes of Iranian secondary school students. Journal of Moral Education, 46(3), 283-294.

Hedayati, N., Kuusisto, E., Gholami, K., \& Tirri, K. (2019). Moral conflicts in Iranian secondary schools. Journal of Beliefs \& Values. doi:10.108o/13617672.2019.1618151

Kamins, M., \& Dweck, C. S. (1999). Person vs. process praise and criticism: Implications for contingent self-worth and coping. Developmental Psychology, 35, 835-847.

Kuusisto, E., Laine, S., \& Tirri, K. (2017). How do school children and adolescents perceive the nature of talent development? A case study from Finland. Education Research International, 2017. doi:10.1155/2017/4162957

Kuusisto, E., \& Tirri, K. (2013). Kasvun ajattelutapa opettajilla ja vanhemmilla: Tapaustutkimus suomalaisista kouluista [Growth mindset of teachers and parents: A case study of Finnish schools]. In Uusi oppiminen [New learning]. Publication of The Committee for the Future. The Parliament of Finland.

Kuusisto, E., Tirri, K., \& Rissanen, I. (2012). Finnish teachers' ethical sensitivity. Education Research International, 2012. doi:10.1155/2012/351879

Laine, S., Kuusisto, E., \& Tirri, K. (2016). Finnish teachers' conceptions of giftedness. Journal for the Education of the Gifted, 39, 151-167.

Magen, Z. (1998). Exploring adolescent happiness: Commitment, purpose, and fulfilment. Thousand Oaks, CA: Sage Publications.

Manninen, N., Kuusisto, E., \& Tirri, K. (2018). Life goals of Finnish social services students. Journal of Moral Education, 47, 175-185.

Mueller, C. M., \& Dweck, C. S. (1998). Praise for intelligence can undermine children's motivation and performance. Journal of Personality and Social Psychology, 75, 33-52.

Narvaez, D., \& Endicott, L. G. (2007). Ethical sensitivity, nurturing character in the classroom. Notre Dame: Alliance for Catholic Education Press.

Rattan, A., Good, C., \& Dweck, C. S. (2012). "It's ok - Not everyone can be good at math": Instructions with an entity theory comfort (and demotivate) students. Journal of Experimental Social Psychology, 48, 731-737.

Rissanen, I., Kuusisto, E., Hanhimäki, E., \& Tirri, K. (2018a). Teachers' implicit meaning systems and their implications for pedagogical thinking and practice: A case study from Finland. Scandinavian Journal of Educational Research, 62, 487-500.

Rissanen, I., Kuusisto, E., Hanhimäki, E., \& Tirri, K. (2018b). The implications of teachers' implicit theories for moral education: A case study from Finland. Journal of Moral Education, 47, 63-77. 
Rissanen, I., Kuusisto, E., Tuominen, M., \& Tirri, K. (2019). In search of a growth mindset pedagogy: A case study of one teacher's classroom practices in a Finnish elementary school. Teaching and Teacher Education, 77, 204-213.

Roberts, B. W., \& Robins, R. W. (2000). Broad dispositions, broad aspirations: The intersection of personality traits and major life purposes. Personality and Social Psychology Bulletin, 26, 1284-1296.

Ronkainen, R. (2018). Kasvun ajattelutavan ilmeneminen opetuksen toteutuksessa ja reflektoinnissa [Growth mindset in teaching and reflection] (Unpublished master's thesis). University of Helsinki, Helsinki, Finland.

Schmidt, J. A., Shumow, L., \& Kackar-Cam, H. (2013). Exploring teacher effects for mindset intervention outcomes in seventh-grade science classes. Middle Grades Research Journal, 10, 17-32.

Tirri, K. (1999). Teachers' perceptions of moral dilemmas at school. Journal of Moral Education, 28, 31-47.

Tirri, K. (2003). The moral concerns and orientations of sixth- and ninth grade students. Educational Research and Evaluation, 9, 93-108.

Tirri, K. (2011). Holistic school pedagogy and values: Finnish teachers' and students' perspectives. International Journal of Educational Research, 50, 159-165.

Tirri, K. (2014). The last 40 years in Finnish teacher education. Journal of Education for Teaching, 40, 1-10.

Tirri, K. (2017). Finland - Promoting ethics and equality. In W. Veugelers, I. de Groot, \& V. Stolk (Eds.), Research for CULT committee - Teaching common values in Europe (pp. 83-9o). Brussels: European Parliament, Policy Department for Structural and Cohesion Policies.

Tirri, K., \& Nokelainen, P. (2007). Comparison of academically average and gifted students' self-rated ethical sensitivity. Educational Research and Evaluation, 13, 587-601.

Tirri, K., \& Ubani, M. (2013). Education of Finnish student teachers for purposeful teaching. Journal of Education for Teaching, 39, 21-29.

Veugelers, W., De Groot, I., \& Stolk, V. (2017). Research for Cult Committee - Teaching common values in Europe. Brussels: European Parliament, Policy Department for Structural and Cohesion Policy. Retrieved from http://bit.ly/2pm5Yh9 